\title{
The Deployment of Broadband Internet in Australia: Areas for Attention and Implications from Canada and Korea
}

\author{
S. Chang^, H. Lee ${ }^{\wedge}$ and C. Middleton $\wedge^{\wedge *}$ \\ shantonc@staff.dis.unimelb.edu.au, heejin@unimelb.edu.au, cmiddlet@ryerson.ca \\ $\wedge$ The University of Melbourne, Australia \\ $\wedge \wedge$ Ryerson University, Canada
}

\begin{abstract}
Broadband Internet connectivity is currently seen as a means to increase the efficiency and competitiveness of an economy. The deployment and use of broadband capabilities is high on the current political agenda in many developed and developing countries, including Australia. But despite ongoing efforts to promote broadband in Australia, deployment has been much slower than expected. This paper aims to identify areas that have been holding up the broadband development in Australia. In examining four areas for attention (demand, competition, price and the role of government), we refer to experiences in Canada and Korea, both leaders in broadband deployment, to show the differences in each area. Although each country discussed here has its own policy agenda and some unique circumstances related to broadband deployment, implications from this paper will provide valuable input for policy makers and industry leaders in Australia (and elsewhere) as they develop strategies to encourage more widespread broadband deployment.
\end{abstract}

\section{Keywords}

Broadband Internet, Canada, Australia, South Korea, Facilities-based competition, ADSL, Cable modems

\footnotetext{
* The authors are listed in an alphabetical order and they equally contributed to the paper.
} 


\section{The Deployment of Broadband Internet in Australia: Areas for Attention and Implications from Canada and Korea}

\section{Introduction}

Broadband has been considered as a key to enhancing competitiveness of an economy and sustaining economic growth (OECD, 2001, 2002; ITU, 2001), and many governments around the world are committed to extending broadband networks to their citizens (BAG, 2003; Office of the e-Envoy, 2001; Task Force on Broadband Communications, 2002).

The Australian Government is keen to deploy broadband across the country, build a foundation for the information society or knowledge economy, and thereby enhance Australia's national competitiveness (BAG, 2003). When compared to other countries, however, Australia is far behind in this race of broadband adoption ${ }^{1}$. According to a recent OECD report, Australia takes the $18^{\text {th }}$ place in the OECD league table of broadband subscription, though the number of broadband subscribers per 100 inhabitants grew to 1.4 in June 2002 from 0.94 in 2001 (OECD, 2002). Despite the fact that up to 7 million homes, or 90 per cent of the population, are ADSL-enabled (Houghton, 2001), there were only about 363,500 subscribers (including 70,500 businesses) at the end of 2002 (ACCC, 2003), about 5\% of the total households. Although the number of subscribers is increasing, the rate of growth slowed during 2002 (Mackenzie, 2003) from 29.2\% in the second quarter to 21\% during the third quarter and to $16.4 \%$ in the December quarter. This slowing trend is worrying and requires further investigation.

Broadband networks are used by businesses and by consumers in their homes. This paper focuses on residential broadband users, because the anticipated societal benefits of broadband networks can only be realized if such networks are widely adopted by consumers. To date in Australia, government efforts to encourage broadband uptake

\footnotetext{
1 Note that there are multiple sources of data on broadband adoption worldwide. Frequently cited statistics come from the OECD $(2001,2002)$ and the ITU $(2003)$ but it is difficult to compare numbers from different sources, and not all sources contain information on all countries. Some statistics measure broadband adoption by numbers of subscribers (e.g. subscribers per 100 inhabitants), others by numbers of households (e.g. percentage of national totals), which are not necessarily comparable.
} 
have centred on suppliers and providers of broadband services. The focus is only now switching from the supply side to the demand side as it becomes increasingly evident that despite available infrastructure, the demand for broadband in Australia continues to be "sluggish" (Firth et al., 2002).

This paper aims to identify areas that have been constraining the broadband development in Australia. Based on previous studies of broadband development in Korea (Lee et al., 2002, 2003), we focus on four areas (demand, competition, price and the government's role). Drawing on a comparison with countries with advanced broadband markets, this paper outlines implications for Australia, which may enable service and content providers and policy makers to build their strategies for faster adoption and prepare for changing markets in the future. Korea and Canada were selected for this comparison because they are leaders in broadband deployment. In addition, Canada has demographic and geographic characteristics similar to Australia (see details in Section 2.2).

This paper consists of five sections. The next section shows why we have selected Canada and South Korea as references. Then we present the current status of broadband in Australia. From this description, we identify areas for attention. In section 4, we discuss these areas while referring to Canadian and Korean experiences in each of the area. The concluding section discusses implications.

\section{Broadband in Canada and Korea}

As seen in Figure 1, Korea and Canada have the highest residential broadband penetration among the world's top 20 economies $^{2}$. In this section, we briefly present the current status of broadband in the two countries.

\footnotetext{
${ }^{2}$ Recent ITU data (2003) also shows a high broadband adoption rate in Hong Kong.
} 
Figure 1. Residential broadband penetration

Residential broadband penetration in top 20 economies (ranked by GDP), 0222002 , percentage of total households

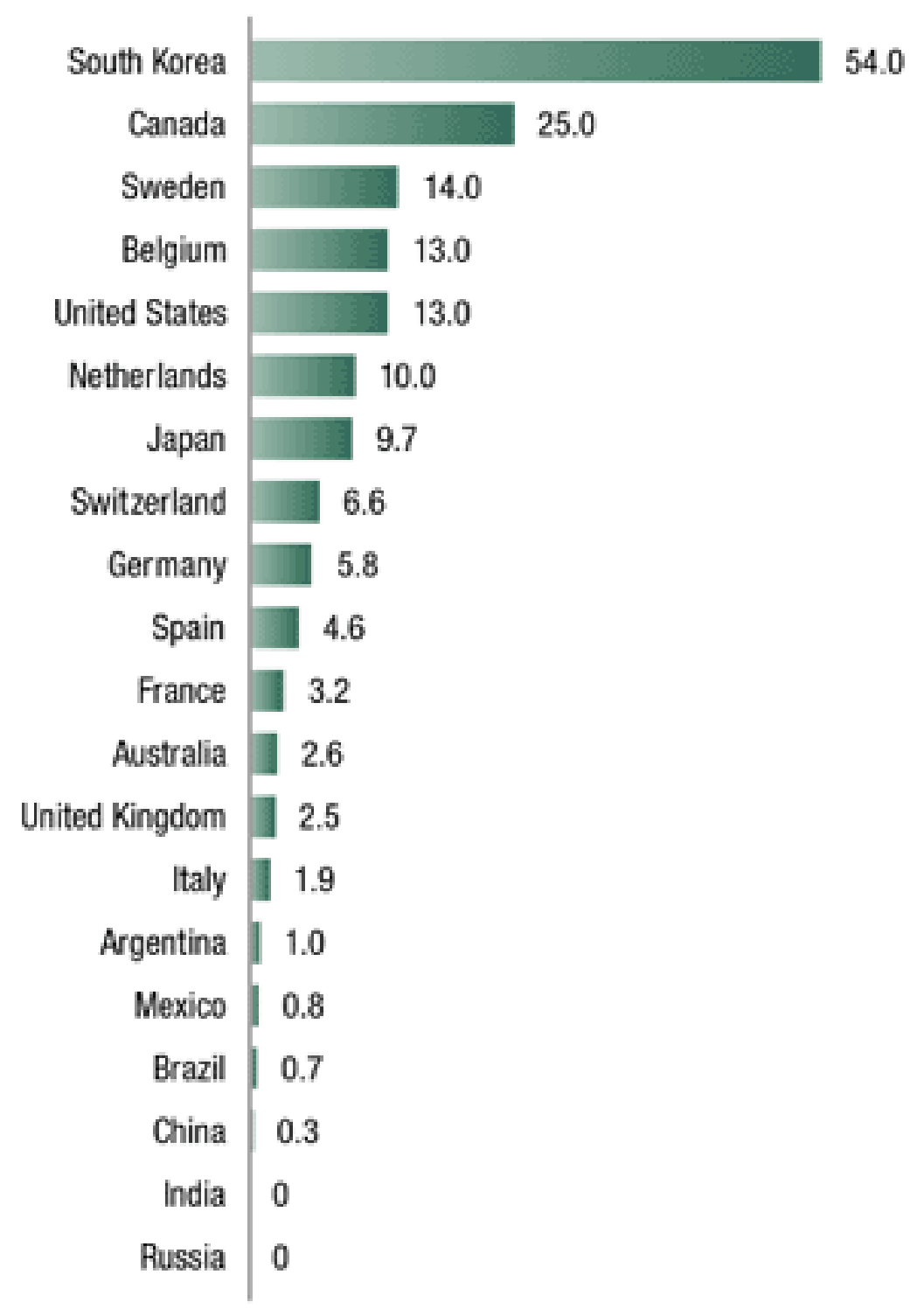

Source: McKinsey proprietary broadband research

Beardsley et al. (2003) 


\subsection{Broadband in South Korea}

South Korea has the highest penetration of broadband in the world. The number of broadband subscribers in Korea reached 10 million in October 2002 (Figure 2). What is more astonishing is that all this was achieved in less than four years after the introduction of the first broadband services in July 1998.

Figure 2. Number of Broadband Internet Subscribers

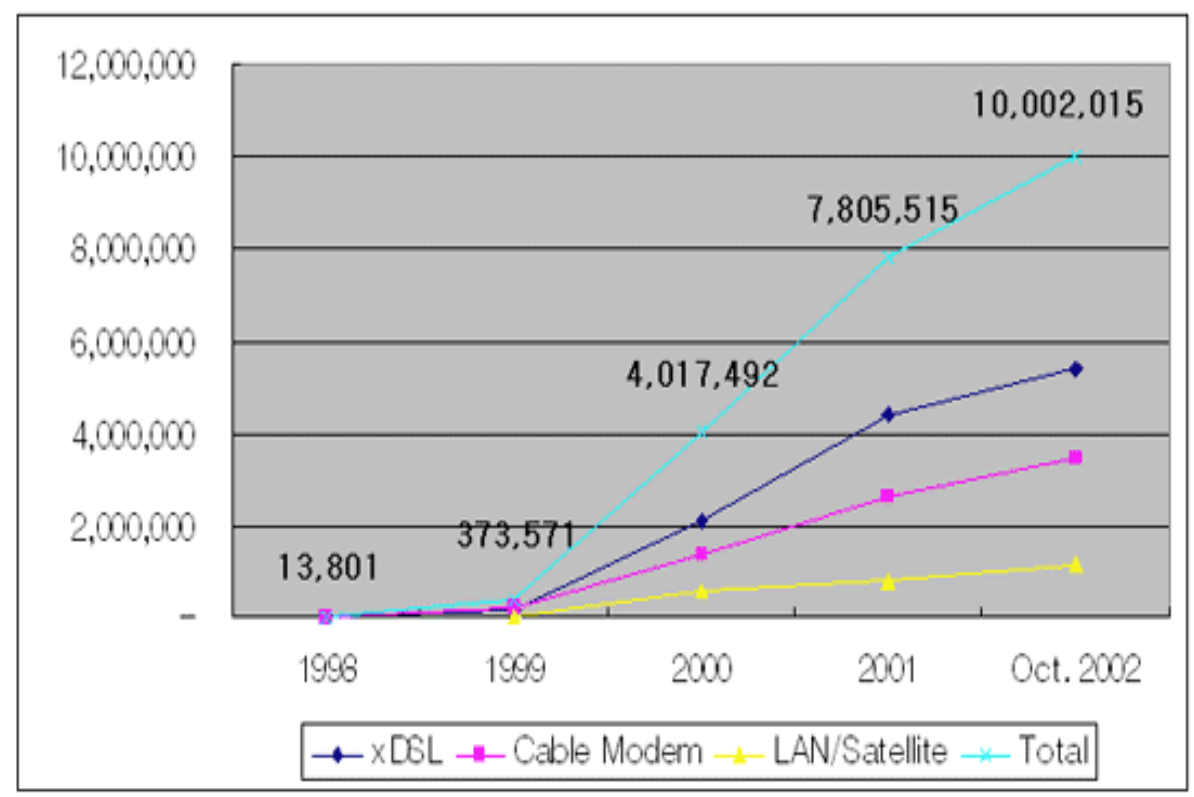

Source: Ministry of Information and Communication (www.mic.go.kr/eng)

The widespread use of broadband has changed the way people use the internet. As Figure 3 displays, Koreans spend more time surfing the web than users in any other countries. In July 2001 Koreans spent an average of 1,340 minutes on- line per user per month. This was longer than Americans (619 minutes) and approximately four times the average number of minutes spent on-line in the UK (382 minutes) ${ }^{3}$. The number of connections per month is also the highest in Korea.

\footnotetext{
${ }^{3}$ For the same period of July 2001, Australians logged up to 13 internet sessions and 415 minutes online (NOIE, 2003). The latest figures of Australia show that the number of sessions per month is 18 , and time spent per month is 619 minutes as of April 2003 (http://www.nielsennetratings.com/news.jsp?section=dat to\&country=au).
} 
Figure 3. Internet Usage

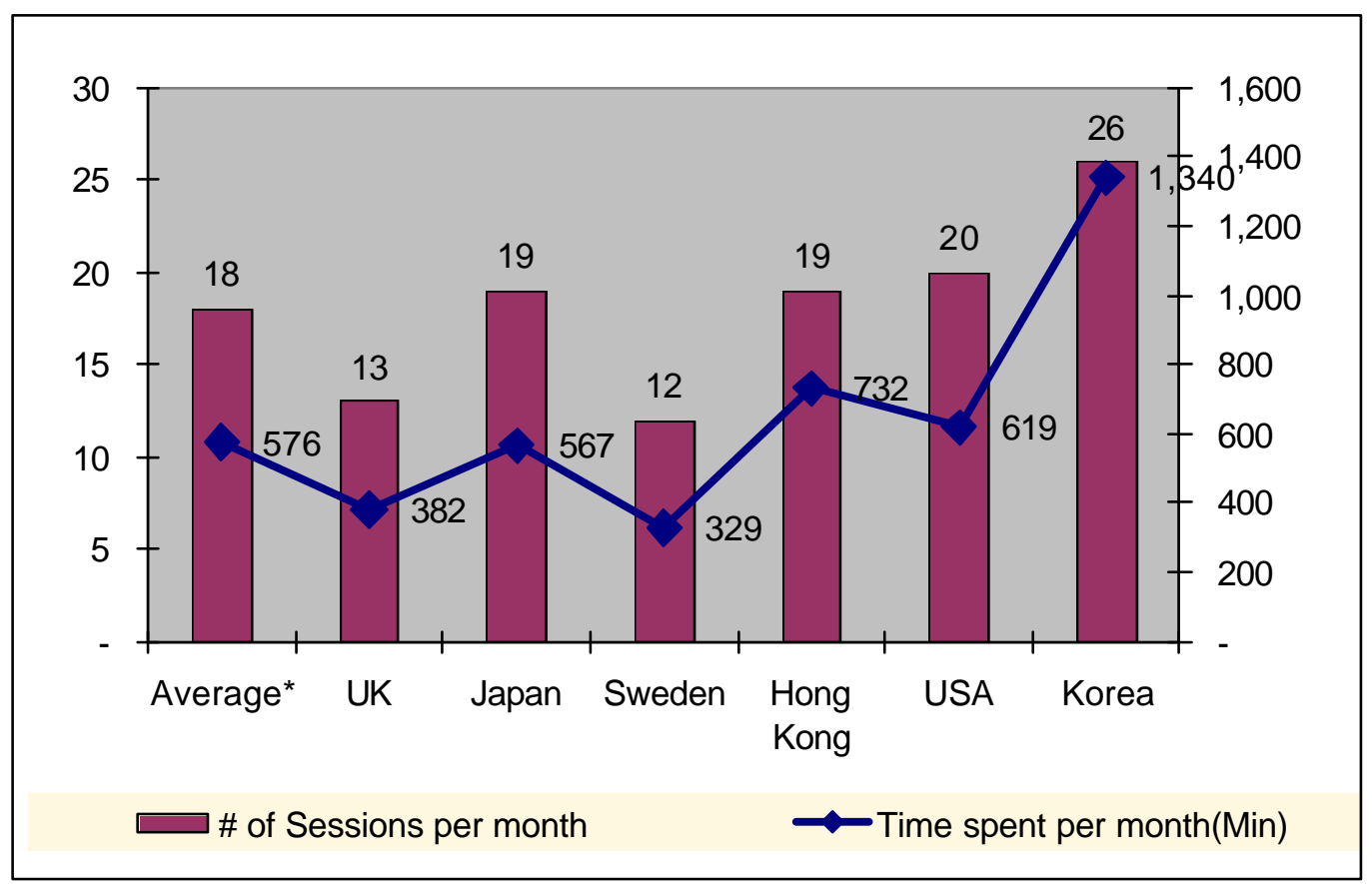

Source: Nielsen/Net Ratings, 2001

Table 1 shows market share by service provider and technology. There are six operators providing broadband services in South Korea. The incumbent operator, Korea Telecom (KT), is the market leader with about $45.8 \%$ market share (4.5 million subscribers), followed by Hanaro Telecom with $28.6 \%$ and Thrunet with $13.1 \%$. In terms of technology, KT primarily uses DSL, Hanaro uses a mix of cable and DSL (depending on the service area), and the Thrunet service is mainly provided via cable modem. Here LAN means the provision of the broadband connection to apartment blocks using telephone lines or UTP (unshielded twisted pair) cable. 
Table 1. Market Share by Service Provider and Technology

\begin{tabular}{|c|r|r|r|r|r|r|}
\hline & \multicolumn{1}{|c|}{ xDSL } & \multicolumn{1}{c|}{$\begin{array}{c}\text { Cable } \\
\text { Modem }\end{array}$} & \multicolumn{1}{c|}{ LAN } & \multicolumn{1}{c|}{ Satellite } & \multicolumn{1}{c|}{ Total } & \multicolumn{1}{c|}{ Ratio } \\
\hline KT & $4,019,724$ & & 556,780 & 6,150 & $4,582,654$ & $45.8 \%$ \\
\hline Hanaro & $1,203,784$ & $1,272,547$ & 388,376 & & $2,864,707$ & $28.6 \%$ \\
\hline Thrunet & & $1,298,348$ & 8,832 & & $1,307,180$ & $13.1 \%$ \\
\hline Onse & & 390,066 & 8,379 & & 398,445 & $4.0 \%$ \\
\hline $\begin{array}{c}\text { Dream } \\
\text { Line }\end{array}$ & 86,200 & 87,001 & 3,302 & & 176,503 & $1.8 \%$ \\
\hline Dacom & & 68,214 & 79,360 & & 147,574 & $1.5 \%$ \\
\hline Others & 74,391 & 332,962 & 117,599 & & 524,952 & $5.2 \%$ \\
\hline Total & $5,384,099$ & $3,449,138$ & $1,162,628$ & 6,150 & $\mathbf{1 0 , 0 0 2 , 0 1 5}$ & $100.0 \%$ \\
\hline Ratio & $53.8 \%$ & $34.5 \%$ & $11.6 \%$ & $0.1 \%$ & $100.0 \%$ & \\
\hline
\end{tabular}

(Source: MIC, 2002, www.mic.go.kr/eng)

The rapid diffusion of broadband internet and its widespread use has led Koreans to perceive broadband as a necessity and taken-for-granted since it is there and very much part of their daily lives (BBC, 2002). As the subscription to ADSL is approaching the saturation point, the Korean market is now set to migrate to a new service of faster speed (VDSL: Very high-bit rate Digital Subscriber Line). VDSL is 5 to 10 times faster than ADSL, providing up to $13 \mathrm{Mbps}$, and it is symmetric. KT and Hanaro recently began to take steps to promote VDSL service to infuse fresh momentum in the broadband service market. They are currently targeting the upscale apartment complexes for VDSL services. Due to the fierce competition, the price is almost the same as that of ADSL. The Korean government, which has recently finalised a new plan to upgrade the country's network up to $20 \mathrm{Mbps}$ by 2005 , is also keen to migrate to VDSL quickly (Yang, 2002). 


\subsection{Broadband in Canada}

Like Korea, Canada has emerged as a leader in consumer broadband adoption. As Table 2 shows, although Australia is smaller than Canada, their economic indicators are similar, as is the multicultural nature of the countries. In addition, both countries have a comparable geographic mix of large urban centres (found along the coast in Australia and along the Canada-US border in Canada) and smaller, geographically isolated communities.

Lee et al.'s $(2002,2003)$ studies of South Korea show that demography, geography and culture are contributing factors to broadband deployment. However, because Korea is quite different from Australia in its geography, demography and culture, the Korean findings have somewhat limited application to Australia. Given the similarities between Australia and Canada, it is suggested that an examination of broadband deployment in Canada provides a useful complement to the Korean studies for Australian policy makers.

Table 2. Factsheet of Australia and Canada

\begin{tabular}{|l|c|c|}
\hline & Australia & Canada \\
\hline Population (2001) & $19.4 \mathrm{~m}$ & $31.1 \mathrm{~m}$ \\
\hline Land area & $7.68 \mathrm{sq} \mathrm{km}$ & $9.2 \mathrm{sq} \mathrm{km}$ \\
\hline Currency rate (US\$ 1) & $\mathrm{A} \$ 1.84(2002$ average) & $\mathrm{C} \$ 1.57(22$ November \\
& & 2002) \\
\hline GDP per head (2001) & US\$ 18,460 22,691 \\
\hline Culture & Multicultural & Multicultural \\
\hline $\begin{array}{l}\text { Broadband subscribers per } \\
\text { 100 inhabitants (from }\end{array}$ & 1.4 & 19.2 \\
OECD, 2002) & & \\
\hline
\end{tabular}

Source: (Country Briefings, Economist.com)

Broadband connectivity has been available to Canadian consumers since late 1996, when the first cable internet service in the world was launched in the Toronto region by Rogers Communications, and SaskTel launched the first commercial DSL service (Lie, 2003). DSL was not widely available until late 1998, when Bell Canada launched its High Speed Sympatico service (Angus TeleManagement, 1998). By the end of 1999, Canadians were ahead of South Koreans in broadband usage, with 455,000 cable modem and 97,180 DSL users (NBI/Michael Sone Associates, 1999). By the end of 
2002, almost $70 \%$ of respondents to an IDC survey indicated they had high speed access at home, with cable modem service more widely used than DSL (see Figure 4).

Figure 4: Internet Access Methods in Canadian Households, 2002
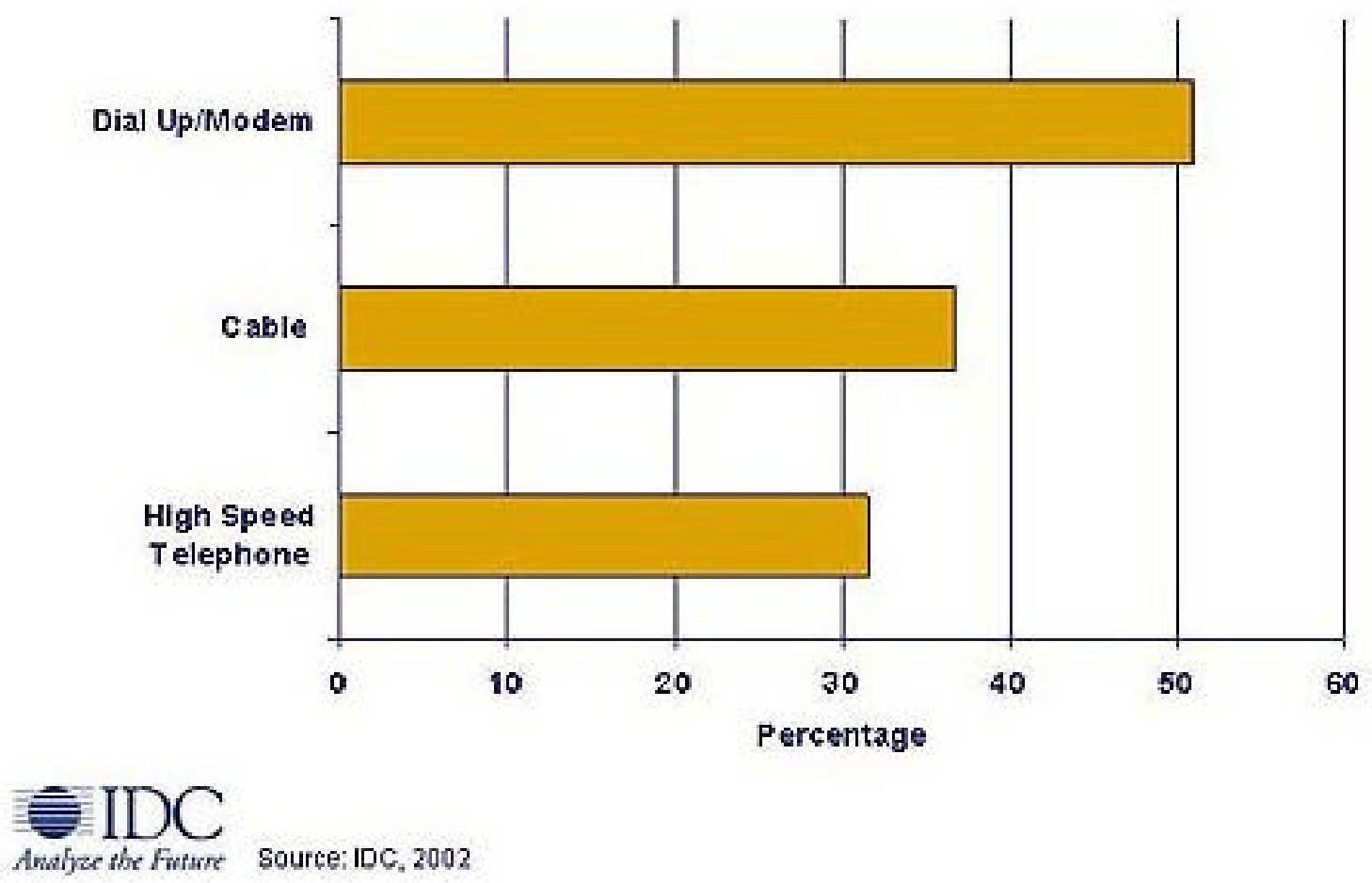

Source: http://www.idc.ca/weeklygraphics/archived/Jan3-9_2003.html

In addition to cable modem and DSL services, a very small proportion of Canadians get high speed internet access via fixed wireless, satellite or fibre to the home (usually in apartment complexes or new subdivisions where fibre was installed when the dwelling was built). In 2001, less than $0.04 \%$ of Canadians used these alternatives to DSL and cable modem access (Lie, 2003). Current government initiatives are focusing on extending broadband access to rural and northern communities in Canada (see http://www.broadband.ic.gc.ca/index_e.asp), as it is estimated that only less than $25 \%$ of Canadian communities have DSL or cable access ${ }^{4}$.

\footnotetext{
${ }^{4}$ Based on overall population figures, Canadians are well-served by broadband providers. However, the estimated 13\% of Canadians who do not have broadband access live in small communities, often situated in remote areas, that commercial service providers do not serve.
} 


\section{Current Status in Australia}

In Australia, the picture is somewhat different. According to the National Office for the Information Economy (NOIE, 2002), in terms of percentage of households that own or lease a computer at home, Australia (64\%) is only second in the world to Korea (70\%). However, in terms of broadband technology penetration, Australia has only been able to achieve 2.6\% compared to Korea's 54\% even though Australia has the second highest broadband reach ${ }^{5}$ (94\%) (behind South Korea at 95\%) among top 20 economies ranked by GDP as of Q2 2002 (Beardsley et al., 2003). As indicated in Figure 3 and Footnote 3, Australians spend less time than the comparative average on the internet.

The number of broadband subscribers in Australia reached 363,500 in December 2002, with residential users making up $64.3 \%$ of this total. Therefore, nearly $2 \%$ of Australians are estimated to be connected to the internet at the speed of over $200 \mathrm{kbps}$ (ACCC, 2003). The following figures are based on actual subscribers to specific broadband technologies (including DSL, Cable, Satellite, and Wireless technologies).

Australia had over 250,000 broadband subscribers at the end of March 2002 as compared to 155,000 at the end 2001. According to the latest statistics (Australian Bureau of Statistics (ABS, 2003) total broadband connections in the region rose by over $47 \%$ during that time period to about 363,500 subscribers as estimated by the Australian Competition and Consumer Commission (ACCC, 2003). This makes Australia one of the top ten countries in the world with respect to growth rate in the number of DSL subscribers towards the end of 2002. However, as mentioned before, despite overall growth, the ACCC (2003) highlighted the slowing down of growth in broadband technology take-up in Australia towards the end of 2002.

\footnotetext{
${ }^{5}$ Here broadband reach means households within reach of broadband networks.
} 
Figure 4. Broadband Internet Subscribers in Australia between 2001 - 2002

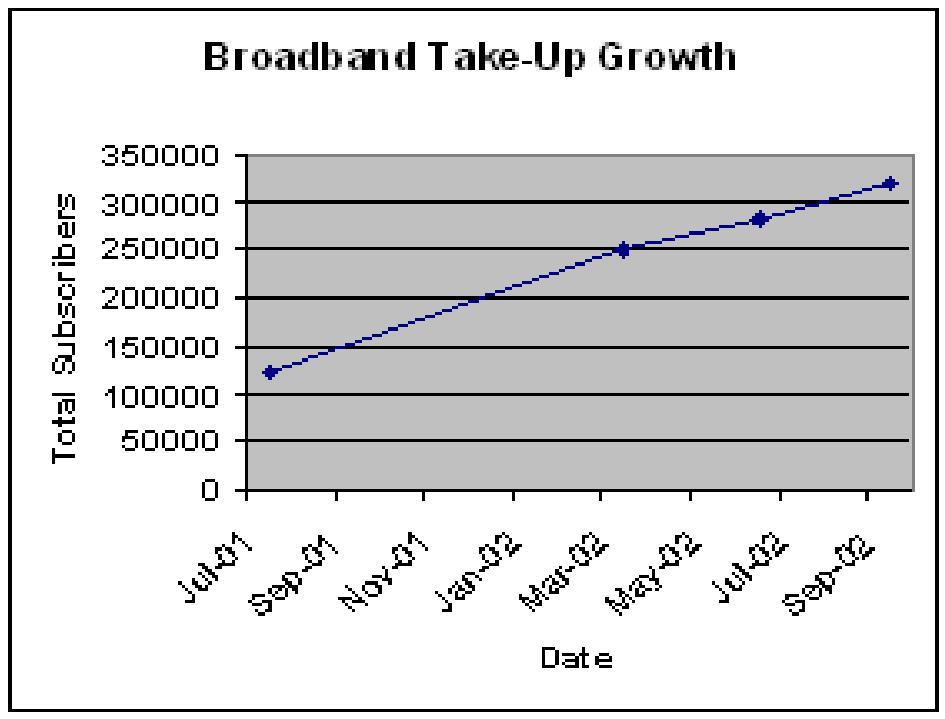

Source: National Office for Information Economy (2003) (http://www.noie.gov.au)

Of the estimated 363,500 broadband subscribers in Australia at the end of 2002, $47.65 \%$ used cable, 38.5\% used ADSL, $10.45 \%$ used other DSL, 3.35\% used satellite, and $0.05 \%$ used other unspecified technology (ACCC, 2003)

In Australia, there are more than 550 internet service providers, many of whom provide broadband services. However, the Australian market is in reality dominated by two main wholesalers, Telstra and Optus. Senator Richard Alston, Australia's Minister for Communications, Information Technology and the Arts recently summed up the state of broadband supply in Australia. Alston (2003) pointed out that access to fixed line broadband telecommunications is characterised by Telstra's ADSL network which is available to about $71 \%$ of the population and in virtually all population centre with greater than 4,000 people. In addition, alternative fixed line broadband networks in Australia are the Telstra and Optus cable networks. More recently, new competitors such as TransACT, Bright Telecommunications and Neighbourhood Cable now also own cable networks which offer cable modem access services (BAG, 2002). With respect to wireless broadband technology, Telstra and Hutchinson Telecommunications have also begun to upgrade and launch their CDMA network respectively (Alston, 2003). Whereas there are many retailers of broadband technology and services, up to very recently, the prices they charge and the coverage they can offer are largely 
determined by the two main wholesalers in Australia, namely, Telstra and Optus. Hence, the charges for ADSL and cable set by most of the retailers investigated are only marginally cheaper than those of Telstra and Optus.

However, Alston (2003) was also optimistic about the government's role in promoting a "competitive and technology-neutral telecommunications industry". In the satellite race, New Skies is expected to provide full service and infrastructure competition to the incumbent satellite operator, Optus. New Skies launched their NSS-6 satellite on 18 December, 2002. Optus is also scheduled to launch its new C1 satellite in June, 2003. Overall, although the number of competitors has definitely increased, the effectiveness of the competitors to match the prices and services of the incumbents in various technologies remain to be seen.

The proliferation of resellers in the Australian broadband market in the last $2-3$ years also means that there is less up to date and reliable data on the actual market share of providers of broadband. The need for a clearer picture is again articulated by the minister. It was reported that the Australian Competition and Consumer Commission (ACCC) has been asked by the minister to provide more detailed statistical data on broadband take up in Australia (Jenkins, 2003). The undertaking includes a more detailed analysis of broadband data by both wholesale and retail sectors, by industry, sectors (residential, business, and government), by geographic areas, by technology types and transmission speed. It is expected that the first report will be made available in November 2003 and from then, every six month on an ongoing basis (Jenkins, 2003).

The need for a more responsive and cohesive strategy on broadband connectivity within Australia has resulted in the Broadband Advisory Group's (BAG) report to the government, Australia's Broadband Connectivity, which outlines key strategies for the government to consider. The Australia government is expected to respond to the recommendations in the coming months (Alston, 2003). The current debate on government legislation and policy in Australia is focused on encouraging broadband take-up within key sectors (demand side), on key performance indicators (KPI) for the incumbent (supply side competition), and on monitoring as elaborated below. 


\subsection{Demand Aggregation and Brokering}

The Broadband Advisory Group's key recommendations for the take up of broadband focus on demand aggregation and on targeting of specific sectors such as education, health, research, and small and medium enterprises (SMES) (BAG, 2003). Demand aggregation refers to the formation of customer demand pooling in order to attract cheaper prices, and new and better services in particular sectors. The strategy is seen as an exercise in building up buying power within a market where the suppliers have significant market power. The report also suggests that there may be a need for a "broker" to identify user and demand patterns, in order to identify opportunities for pooling and to broker cooperation between different sectors (BAG, 2003). The report cites the Australian Academic and Research Network (AARNet) as a successful example of such brokerage, which now provides high-capacity internet services for the universities and research institutes in Australia.

\subsection{Key Performance Indicators (KPIs) for Incumbent}

On the supply side, there is an ongoing debate between the ACCC and Telstra. The Australian government introduced legislative changes that were aimed at making the incumbent (Telstra) more transparent. The focus was on making sure that there is to be accounting separation of Telstra's wholesale and retail arms. Two initiatives resulted from the effort. First, a set of model terms and conditions needs to be developed to guide future commercial agreements on access to core services (such as LLU), as seen by the Productivity Commission. The second initiative arises from the need to develop KPIs in relation to Telstra's supply of both wholesale and retail services, which assess Telstra's performance in relevant non-price areas. The debate is ongoing and the need to develop both the model terms and conditions and non-price KPIs are currently being investigated by the Commission (ACCC, 2003).

\subsection{Monitoring}

The two main organisations (other than the suppliers) in Australia that are driving the growth of broadband are the National Office for the Information Economy (NOIE) and the ACCC. Whereas the NOIE has been largely responsible for independent research 
and advice to the Australian government on broadband strategy, the ACCC has been focusing on a number of initiatives to increase the competition within the telecommunications industry in Australia. Interestingly enough, the Broadband Advisory Group (which is situated within the NOIE) has recommended in their report that the ACCC should be required by the government to monitor and report on the progress of ensuring competition in the market (BAG, 2003).

\section{Main Areas for Attention}

\subsection{Competition}

It is often argued that kealthy competition both between infrastructure networks (e.g. cable modem, DSL, fixed wireless, satellite) and within each network technology (e.g. ADSL) plays a pivotal role in the deployment of broadband Internet (OECD, 2001). In Korea there was, and is, vigorous infrastructure competition within and between ADSL and cable modem networks. The Korean broadband access market is characterised by strong facilities based competition in which three main companies compete. Entrants have to build their own network in infrastructure competition whereas entrants can use the incumbent's network and resell capacity on it in service competition (Christodoulou and Vlahos, 2001; Michalis, 2001).

When KT dominated the voice market, new entrants focused on data services for their market entry strategies. Thrunet and Hanaro were able to gain market access initially by leasing network capacity from Powercomm. Hanaro later added its own DSL networks to the HFC (Hybrid Fibre Coaxial) networks leased from Powercomm. They were able to gain rapid subscriber growth by targeting large multi-dwelling apartment complexes and other high-density areas. KT initially stuck to ISDN and believed that its firm grip on the telecommunication network would protect its market share. But Hanaro's aggressive marketing led KT to follow suit quickly by launching its own ADSL service.

In Canada, broadband competition is primarily between infrastructure networks, with cable modem access having larger market share than DSL. In most urban areas there is only one cable modem provider (usually Shaw or Rogers) and one DSL service provider (Sympatico in most provinces), so consumers' choices for broadband service are 
between cable and DSL. The competition between the two access modes is fierce. In television advertising DSL providers touted the benefits of a connection that is not shared with others in a community (cable modem speeds decline noticeably as more users are added to the network within a specific geographic region), and cable companies retaliated with claims that users of the phone company's service could suffer "download rigor mortis", suggesting that cable internet access was faster than phone access (http://www.strategymag.com/aoy/2000/maclaren/athome), even though DSL and cable modem speeds were comparable. Most urban areas are now well-served by both DSL and cable providers, but there remain some isolated pockets where DSL is not available (usually due to the distance from a local exchange to the customer premise). As noted earlier, small remote communities rarely have DSL or cable modem access, and must rely on alternative access modes (e.g. satellite) for connectivity.

Both DSL and cable providers are required to provide open access to their facilities, allowing others to offer DSL and cable modem access without building their own network infrastructure. In the DSL market some providers (e.g. Primus) have taken advantage of this co-location opportunity to establish competing DSL services, resulting in some customer "churn" as people move from one provider to another to take advantage of introductory subscriber offers. To date, there is little evidence of competing services being offered via existing infrastructure in the cable sector, so there is effectively no competition within the cable sector. Service providers have divided the market based on geography, and each geographic area has only one cable provider. However, AOL has recently announced its entry into the broadband market in the province of Ontario, and has indicated that it may lease cable infrastructure to develop this service (Ross, 2003).

In Australia, ADSL and cable are the most popular broadband technologies. However, the ADSL and cable networks are dominated by Telstra and to a lesser extent, by Optus. As suggested by Kidman (2003), "This lack of choice is largely because ISPs themselves have little choice when purchasing broadband services on the wholesale market". In addition, Lynch (2003) argued that Telstra has resisted the widespread rollout of ADSL which is a threat to its ISDN service. Like most countries, LLU is seen 
as crucial to competition. The main motivation of LLU is to bring competition in the local loop market. In Australia, the local loop unbundling enables the incumbent's (Telstra's) competitors to install infrastructure in local exchanges to provide broadband services such as ADSL. Telstra has argued consistently that the simultaneous challenge of ADSL and LLU has been a major impediment to growth, citing Australia as the only place where simultaneous DSL and LLU rollout has been in place, due to pressures from the ACCC (Macleod, 2001). It is also argued that incumbents had incentives to delay LLU until they were ready to compete in broadband access. LLU \& clearly a contentious area for incumbents as can be seen by the New Zealand example where Telecom (New Zealand's incumbent) is opposed to LLU, while its Australian subsidiary (AAPT) is keen to take advantage of unbundling in Australia (Watson, 2002)

In Korea and Canada, The aggressive tug-of-war between facility-based service providers utilizing different access technologies has had the effect of lowering prices in order to pre-empt the market in the early phase of its development. The low flat fee for a quality service, in turn, created a greater demand for high-speed Internet access among consumers, and thereby allowed the size of the market to grow exponentially.

\subsection{Pricing}

The Korean government recognised that to be successful, broadband access would need to be priced at affordable levels for middle-income households. This was estimated to be approximately US\$30 per month. The fierce competition described above pushed further down prices, and the prices have now stabilised at US\$25 per month for broadband Lite (2 Mbps including modem rental) and US\$33 per month for broadband Pro (8 Mbps including modem rental). At these price levels, broadband is seen as affordable and attractive.

In Canada, there is little price competition for broadband services. For the standard offering ( 1-1.5 Mbps downstream, 200Kbps upstream), both DSL and cable providers charge $\$ 45$ (CAD) per month ( $\$ 33 \mathrm{USD})$, with introductory offers that reduce the price for the first months of service, and package deals for subscribers who also get other services from the provider (e.g. cable television or telephone services). 
For many early adopters of broadband, this pricing structure made broadband a good alternative to the common practice of North American households in late 1990s where a second telephone line was purchased in addition to paying an ISP (for a total monthly cost of $\sim$ \$38USD). Now consumers who do not have a second phone line, but still would like to free up the phone line while on the internet, are being offered broadband "light" services, which cost just slightly more than basic dial up but provide the always on, and "no busy signal" benefits of broadband. These "light" services are not fast ( $128 \mathrm{Kbps}$ ), but do appeal to users whose activities include e-mail and web browsing, but not much downloading of large files. It could be argued that for many Canadians, regular or light broadband has been adopted because of the benefits it provides for only a small increment over the cost of dial up access.

In the past year, DSL providers have implemented a bandwidth cap of 10GB for total monthly uploads and downloads. DSL Ultra service offers up to 20GB of data transfer monthly for about \$50USD, with additional charges made for excess data transfers. Currently there are no bandwidth caps on cable modem service, but it is expected that caps will be introduced at some point in the future.

In Australia, MacLeod (2001) from Telstra argued that pricing is not the issue in Australia as it is comparable to the rest of the world. The Australian government also maintains at large that Australia's broadband prices are comparable to the rest of the world although they acknowledge that there are download limits in Australia (Department of Communications, Information Technology, and the Arts, (DCITA), 2003). Australia's broadband service prices start from about US $\$ 20$ per month as well. Yet, perhaps the issue here is not the relative price of Australian broadband services in comparison with that of Korea and Canada, but the relative difference between the price of broadband services and dial up service. Australia has the among the lowest diat up internet prices in the world (slightly lower than Canada). Therefore, it is difficult to convince consumers to switch away from dialup to broadband unless there are perceived benefits of broadband. In addition, as seen in Table 3, when it comes to price per $100 \mathrm{Kbps}$, the price in Australia is still expensive. In terms of the price of broadband 
as percentage of monthly income, however, it is not cheap in Korea. This observation leads us to see other factors than price.

Table 3: Comparative Pricing Data

\begin{tabular}{|l|c|c|}
\hline & $\begin{array}{l}\text { Price of Broadband } \\
\text { Connection as \% of } \\
\text { Monthly Household } \\
\text { Income }\end{array}$ & $\begin{array}{l}\text { Price per 100 Kbps of data } \\
\text { per month, \$USD }\end{array}$ \\
\hline Korea & 3.0 & 0.29 \\
\hline Canada & 1.6 & 3.06 \\
\hline Australia & 3.4 & 4.42 \\
\hline
\end{tabular}

Source: http://www.itu.int/osg/spu/ni/promotebroadband/presentations/01-reynolds.pdf

\subsection{Demand}

Given the number of broadband subscribers in countries like Korea and Canada, it is clear that there is consumer demand for broadband services. But what is less clear is the nature of this demand, in terms of what consumers are actually doing with broadband once they acquire it. Government policy documents frequently identify the benefits of broadband service for access to e-learning, e-government and e-health (e.g. National Broadband Task Force, 2001; Office of Technology Policy, 2002). But Bauer et al. (2002) argue that the majority of such services can be delivered to consumers using relative low bandwidth. There are efforts by governments to promote demand for broadband (see http://www.itu.int/osg/spu/ni/promotebroadband/ for recent activities in this regard), and there is an ongoing discussion about the role of "killer applications" and content in encouraging broadband uptake (Middleton, 2002a)

The Korean case provides interesting insights into the nature of demand for broadband. Consumers' awareness of fast Internet was very high even before the commercial launches of ADSL and cable modems for residential users. This awareness level can be attributed mainly to PC Bangs ('bang' meaning a room, similar to Internet Cafe s) which are equipped with high-speed leased lines and multimedia computers, and offer highspeed access to the Web at affordable prices. In December 1998 (before the ADSL commercial launch), there were about 25,000 PC Bangs (Lee et al., 2003). Many 
Korean users were first exposed to high-speed access to the Web in PC Bangs. They became so accustomed to using high-speed services that they were not able to return to dial-up methods at home. This is an important factor that has made the high-speed Internet connection like ADSL a norm among Korean people.

Another driver of broadband is online games which acted like a 'killer application' (Lee et at., 2003). Young generations played online games in PC Bangs at high speed and a low price. The types of games popular in Korea such as Starcraft and Lineage are Massively Multi Player Online Games, and they require high bandwidth for transmitting graphic data. Online games drove people to subscribe the fast speed Internet at home, and they are considered an inevitable part of the Korean broadband development despite occasional negative coverage in the media ${ }^{6}$.

In Canada, there are many government programs designed to stimulate demand for broadband services, and to develop broadband content (see http://www.canarie.ca/funding/ for a list of funding opportunities for content and application development). The federal government has been active in enabling internet connectivity. For example, by March 1999 all schools and public libraries were connected to the internet via the SchoolNet initiative. Now that basic connectivity is in place, efforts are being made to provide higher bandwidth connections in public places across the country.

Interestingly, consumer demand for broadband in Canada seems to grow independently of these government initiatives. From a consumer perspective, broadband is being used to create and share content (e.g. music, video files), to communicate with others (e-mail, messaging), and for information gathering (web searches). Consumers do partake in online learning activities (e.g. accessing course materials), they access government information and conduct various transactions (e.g. renewing parking permits), and search for health care information online, but it is not clear that these are their primary

\footnotetext{
${ }^{6}$ While there is concern that the Internet is used too much for entertainment rather than for serious pursuits of, say, education, others argue that the benefits of broadband will emerge even if the driver of connectivity is access to entertainment (ITU, 2001)
} 
activities. One of the authors is conducting a study of Canadian consumer demand for broadband that will investigate these issues further. It is anticipated that the primary uses of broadband identified in this study will be entertainment-based, rather than oriented to the services being promoted by government (e-learning, e-health, etc.). It is also noted that despite the demise of partnerships initially in place between service and content providers (e.g. Rogers cable modem service accessed the Excite@Home network to provide users with specialized broadband content), users still find value in their broadband connections, becoming content developers themselves (Middleton, 2002b) and accessing content via peer to peer sharing services.

There is also a debate in Australia on whether there is a demand from consumers for broadband access which can sustain such a rate. First of all, it seems that the awareness and experience of broadband among the public is low in Australia. The low awareness here in Australia is highlighted by the BAG (2003) report which consistently recommends public education on the benefits of broadband technologies. Wale (2002) suggested that even some Australians who have been exposed to the use of broadband do not have a full appreciation of its potential, and lack awareness about comparative costs of broadband and dial-up. Wale (2002) suggested that there is also little understanding in the public of the differences in the different broadband technologies and what they mean for users.

The discourse on demand then moves on to contents. This leads to questions like 'Is there a killer application which forces customers to buy broadband access?' Killer applications force or urge users to buy or adopt the platform on which the application is running (Downes et al., 2000). However, as suggested by Wale (2002) and Sacks (2002), there are few compelling applications for which broadband is essential in Australia. Both Wale (2002) and Sacks (2002) indicated that there might be more interest amongst Australian users in the attributes of broadband rather than applications for two main reasons. First, the focus seems to be still on the connectivity (always on) and capacity to network (within households and organisations) that are still more attractive. This has also been the mainstay of advertising for broadband services. Second, Wale (2002) and Sacks (2002) both argue that the lack of importance placed on applications in Australia 
may be due in part to factors such as capped speed and charging by volume download. This means that for users, applications that are heavily based on broadband (which may have high volume) are still not attractive to Australian users both within households and organisations.

\subsection{Government role}

There is a growing trend of government intervention in IT innovation (King et al., 1994) and Internet diffusion (Press et al., 1998). This remains true of broadband. There is a debate in many countries surrounding the role of government in deploying broadband.

First of all, the Korean government maintained a consistent policy for competition in telecommunications sector in general, and in the Internet sector in particular. There has been little entry regulation for Internet services. The government's "hands-off policy" (Park \& Lee, 2002) allowed any businesses which wanted to provide high speed Internet access to start and provide a variety of services following a simple registration procedure. The government also ignited service competition by monitoring and announcing the services (e.g., actual connection speed, days taking for installation, etc.) provided by the companies.

On the demand side, the government implemented several policy measures to create Internet demand and thereby to promote and boost the broadband penetration and use. These include IT and Internet literacy programmes, among which a programme targeting at housewives is seen to have contributed to forming an Internet boom among females (Lee et al., 2003).

In Canada, Industry Canada (a federal government department) established a National Broadband Task Force in 2001 to advise the government on how broadband technologies could "enhance opportunity and prosperity" for Canadians. The task force report (http://broadband.gc.ca./Broadband-document/report_e.asp) identified a goal of "ensuring that broadband services are available to businesses and residents in every Canadian community by 2004". This date has since been revised to 2005 . The report suggests that government investment in broadband infrastructure should only take place 
in underserved areas ("First Nations, northern, remote and rural communities which are currently unserved by Digital Subscriber Line (DSL) or cable modem service" http://www.broadband.gc.ca/index_e.asp), as private sector telcos and cable companies have provided infrastructure to consumers in profitable locations.

In comparison with a country like Korea, government investment has had a minimal role in creating an environment for private sector development of broadband networks. Like Korea however, there are few regulations in place for internet service providers, making it easy for new market entrants to engage in facilities-based competition. Cable providers are mandated to provide access to their networks, and local loop unbundling allows companies without their own infrastructure to enter the DSL market (Lie, 2003).

In Australia, the National Office for the Information Economy (NOIE) was established in 1997 to develop and coordinate advice to the Australian Government on information economy issues. The NOIE's work is focused on the aims and objectives set out in The Strategic Framework for the Information Economy and the subsequent progress reports (NOIE 2003). The areas of attention include access and participation, adoption of ebusiness, building public trust and confidence in online services, e-Government, understanding the information economy, and international collaborations. However, these are broad aims that look at building Australia's information economy through encouraging ebusiness and egovernment and addressing the digital divide within Australia. The aims are not necessarily targeted at broadband uptake in Australia.

In an effort to specifically tackle the issue of broadband deployment in Australia, the Broadband Advisory Group (BAG, which works out of the NOIE) was established in March, 2002. The group was to provide "high level advice" $b$ the government on broadband policies, to optimise benefits for Australia from broadband adoption (NOIE 2003). After a year of consultation with suppliers and users in the industry, businesses, community groups and government bodies, there is a call for the Australian government to provide a "vision" for the future of broadband in Australia. However, there is still no agreement on what this "vision" should be. Primarily, in a series of forums organised by BAG, there was discussion about whether the government should interfere or just let the 
market do the work (NOIE, 2002). However, there was agreement that government strategy should focus on public awareness amongst businesses and community groups, on demand aggregation where groups (particularly in rural areas) can work together to purchase broadband service, on competition amongst suppliers, and on monitoring the competition (BAG, 2003). The effectiveness of these policies and the form they will take remains to be seen.

\section{Conclusion}

This paper has compared the broadband development in Australia, South Korea and Canada. We have identified four areas for attention in the deployment of broadband Internet: competition, price, demand and the government's role. In examining these factors, we made references to the Korean and Canadian cases.

In closing the paper, we highlight the following two facts. First, Korea and Canada have made it within only three or four years' time. Second, 90\% of Australian households are with ADSL reach, which are around 7 million bmes. Deploying broadband access is not just a matter of building networks. Rather, it has more to do with economics, policies, and strategies surrounding competition, promotion, marketing and sociocultural atmosphere as seen in the Korean and Canadian cases. Therefore, in summary, here in Australia, it may be important to pay attention to public awareness and understanding of the potential of broadband (attributes and applications), relative pricing of broadband services to dialup service, the volume download caps and limits, and a balance in government attention to both demand and supply of broadband services. We suggest that fast penetration is feasible and possible in Australia when a momentum is given.

\section{References}

Australian Bureau of Statistics. (ABS). (2003). Internet Activity, Australia, Cat. 8153.0. http://www.abs.gov.au/Ausstats/abs\%40.nsf/e8ae5488b598839cca25682000131 612/6445f12663006b83ca256a150079564d!OpenDocument (Last viewed on $10^{\text {th }}$ June 2003)

ACCC. (2003). Snap shot of broadband deployment as at 31 December 2002. http://www.accc.gov.au/telco/fs-telecom.htm. (Last Viewed on 2 April 2003). 
Alston, R. (2003). Regulating a Converging Environment, ABN AMRO

Communications Conference 2003, Sydney.

Angus TeleManagement. (1998). "Bell launches DSL Lite", Telecom Update, No. 162, December 14.

http://www.angustel.ca/update/up162.html\#BELL\%20LAUNCHES\%20

DSL\%20LITE. (Last Viewed on 25 May 2003).

BAG. (2003). Australia's Broadband Connectivity: The Broadband Advisory Group's Report to Government.

http://www.noie.gov.au/publications/NOIE/BAG/report/index.htm (Last viewed on 10th June 2003)

Bauer, J. M., Gai, J., Kim, T. A., Muth, S., \& Wildman, S. (2002). Whither Broadband Policy. Proceedings of the Telecommunications Policy Research Conference, Alexandria, VA.

BBC. (2002). Broadband lessons to be learned. 11 October.

http://news.bbc.co.uk/1/hi/technology/2319879.stm. (Last Viewed on 7

November, 2002).

Beardsley, S., A. Doman, et al. (2003). Making sense of broadband. McKinsey Quarterly 2. www.mckinseyquarterly.com (Last viewed on 13th May 2003).

Christodoulou, K. and Vlahos, K. (2001). Implications of regulation for entry and investment in the local loop. Telecommunications Policy 25: 743-757.

DCITA. (2003). FAQ - Broadband Services in Australia. http://www.dcita.gov.au/Article/0,0_1-2_3-4_108466,00.html (Last viewed on $10^{\text {th }}$ June 2003)

Downes, L., Mui, C. and Negroponte, N. (2000). Unleashing the Killer App: Digital Strategies for Market Dominance. Boston, MA: Harvard Business School Press.

Firth, L., Gillwald, A., Houghton, J., Morris, P., Prosperetti, L., and Merini, M. (2002). Broadband: Four Nation's Experiences. Journal of Network Industries, 3(2): 183-222.

Houghton, J. (2001). Australian Broadband Case Study. www.itu.int/broadband/australiafinal. Viewed on 1 November, 2002.

ITU. (2001). A broadband future: Reconciling opportunities and uncertainties. ITU News. 6.

ITU. (2003). Promoting broadband: Background paper, International

Telecommunication Union. www.itu.int/broadband. Accessed on 9 April 2003.

Jenkins, C, (2003). Alston breaks out broadband. The Australian. 8 May. http://australianit.news.com.au (Last viewed $10^{\text {th }}$ June 2003)

Kidman, A. (2003). The impression of choice is an illusion. IT Business Special Report: Broadband, The Australian. April 1.

King, J.L., V. Gurbaxani, K.L. Kraemer, F.W. McFarlan, K.S. Raman, and C.S. Yap. (1994). Institutional factors in information technology innovation Information Systems Research, 5, pp.139-169.

Lee, H., J. Choudrie et al. (2002). Investigating Broadband Technology Deployment in South Korea. Brunel-DTI International Technology Services Mission to South Korea.

Lee, H., O'Keefe, R. and Yun, K. (2003). The Growth of broadband and electronic commerce in South Korea: Contributing factors. The Information Society. 19: 81-93. 
Lie, E. (2003). Promoting Broadband: The Case of Canada. International

Telecommunication Union.

http://www.itu.int/osg/spu/ni/promotebroadband/casestudies/canada.doc. (Last Viewed on 25 May 2003).

Lynch, A. (2003). Duopoly keeps prices up. The Australian. IT Business Special Report: Broadband. p. 9.

Mackenzie, K. (2003). Broadband growth slows. The Australian. 20 March. http://australianit.news.com.au (Last Viewed on $10^{\text {th }}$ June 2003)

MacLeod, V. (2001) Broadband in Australia. World Information Technology and Services Alliance Presentation. http://www.witsa.org/presentations/Telstra.pdf (Last viewed on 10th June 2003)

Michalis, M. (2001). Local competition and the role of regulation: the EU debate and Britain's experience. Telecommunications Policy, 25: 759-776.

Middleton, C. A. (2002a). Who Needs a 'Killer App'? Two Perspectives on Content in Residential Broadband Networks. Journal of Research and Practice in Information Technology, 34 (2): 67-81.

Middleton, C. A. (2002b). Exploring Consumer Demand for Networked Services: The Importance of Content, Connectivity and Killer Apps in the Diffusion of Broadband and Mobile Services. In Applegate, L., Galliers, R., \& DeGross, J. I. (Eds.), Proceedings of the Twenty-Third International Conference on Information Systems: 391-399. Barcelona: AIS.

National Broadband Task Force. (2001). The New National Dream: Networking the Nation for Broadband Access, Industry Canada, Ottawa.

NBI/Michael Sone Associates. (1999). Canadian Internet Service Providers Market Report. December.

Nielsen/NetRatings Global Internet Index. 24 August. www.nielsen-netratings.com. Last Viewed on 6th February 2002.

NOIE (2002a). Australia's Position Relative to other Countries. http://www.noie.gov.au/projects/framework/Progress/ie_stats/CSOP_April2002/ index.htm (Last viewed on 10th June 2003)

NOIE (2002b) Report of Broadband Advisory Group Consultative Forums http://www.noie.gov.au/projects/framework/Priorities/BAG/Forums_reportFinal.pdf (Last viewed on 10th June 2003)

NOIE (2003) Broadband Advisory Group http://www.noie.gov.au/projects/framework/Priorities/BAG.htm (Last viewed on 10th June 2003)

OECD. (2001). The Development of Broadband Access in OECD Countries. Committee for Information, Computer and Communications Policy, Directorate for Science, Technology and Industry.

OECD. (2002). Broadband Access for Business. Committee for Information, Computer and Communications Policy, Directorate for Science, Technology and Industry.

Office of Technology Policy. (2002). Understanding Broadband Demand: A Review of Critical Issues. Washington, DC: U.S. Department of Commerce.

Office of the e-Envoy, (2001). UK Online: The Broadband Future.

Park, J. and Lee, J., (2002). The prospect and policy directions of the broadband

Internet market. Telecommunication Market 40: 73-88. (In Korean). 
Press, L., Burkhart, G., Foster, W., Goodman, S., Wolcott, P. and Woodard, J., (1998). An internet diffusion framework. Communications of the ACM 41(10): 21-26.

Ross, R. (2003). AOL to launch high-speed Internet service in Ontario. Toronto Star. 27 May 2003. p. C3.

Sacks, G. (2002). Determinants of Broadband Adoption for NGOs in the Healthcare Industry. Honours Thesis, University of Melbourne.

Task Force on Broadband Communications. (2002). Task Force on Broadband Communications Report. Italy: Ministry of Communications, Minister for Innovation and Technologies.

Watson, D. (2002). Unbundling to be investigated. Computerworld. www.computerworld.co.nz (Last Viewed on $10^{\text {th }}$ April 2003).

Wale, C (2002) In search of the elusive "killer application" that will drive broadband uptake in Australian households. Honours Thesis, University of Melbourne

Yang, S. (2002). Korea leads broadband internet service market. The Korea Herald. 13 November. http://www.koreaherald.co.kr. (Last Viewed on $22^{\text {nd }}$ November 2002). 